\title{
The twisted path from farm subsidies to health care expenditures
}

\author{
Stephanie Bernell \\ School of Social and Behavioral Health Sciences, Oregon State University, Corvallis, USA; Stephanie.Bernell@oregonstate.edu
}

Received 10 November 2012; revised 14 December 2012; accepted 20 December 2012

\begin{abstract}
Overweight and obese individuals are at increased risk for many diseases and health conditions, including but not limited to the following: hypertension; osteoarthritis; dyslipidemia; type 2 diabetes; coronary heart disease and stroke. Consequently, individuals who are obese are more likely to use health services and are more likely to use costly health services than non-obese individuals. Between 1987 and 2001, growth in obesity related health expenditures accounted for 27 percent of the growth in inflation-adjusted per capita health care spending. Researchers, popular press and the television news media have paid considerable attention to the effect that farm subsidies have on dietary habits and obesity. Prominent researchers in the field have concluded that US farm subsidies have had a negligible impact on obesity. However, even small increases in obesity rates are associated with higher health care expenditures. The primary intent of this study is to break down the linkages from farm subsidy to health expenditure and shed light on the unintended implications of the farm subsidy program. We find that agricultural subsidies have the potential to influence health care expenditures.
\end{abstract}

Keywords: Obesity; Farm Subsidy; Health Expenditure; Cost; Medicare; Medicaid

\section{INTRODUCTION}

Amongst all of the health care issues discussed by the public health community, the growth in obesity rates is frequently cited as one of the most pressing health care concerns in the United States and around the world. Worldwide, more than 1 billion adults are overweight and at least 300 million are clinically obese. Obesity rates vary from less than $5 \%$ in China and Japan to over $24 \%$ in Mexico. But even in relatively low prevalence coun- tries like China, rates in some cities (i.e., Shanghai) are increasing dramatically [1].

In the United States there were notable increases in the prevalence of individuals who were either overweight or obese in the last 25 years; and recent data indicate that more than half of US adults are considered overweight and one-third are considered obese [2].

Overweight and obese individuals are at increased risk for many diseases and health conditions, including but not limited to the following: hypertension; osteoarthritis; dyslipidemia (i.e., high total cholesterol or high levels of triglycerides); type 2 diabetes; coronary heart disease and stroke [3,4]. Consequently, individuals who are obese are more likely to use health services and are more likely to use costly health services than non-obese individuals [5, $6]$.

While obesity rates were rising, national health care expenditures in the United States were also rising. Health care spending grew from 5.1 percent of US Gross Domestic Product (GDP) in 1960 to 8.8 percent in 1980; and by 2006, spending on health care reached just over $16 \%$ of the GDP, or about \$2 trillion [7].

The increase in health expenditures was, at least in part, due to rising obesity rates. In fact, between 1987 and 2001, growth in obesity related health expenditures accounted for 27 percent of the growth in inflation-adjusted per capita health care spending [8]. In absolute terms, obesity accounts for 5.5 to 7 percent of national health expenditures in the US [9-13]. The public portion of this amount is quite substantial; federal and state coffers finance approximately half of the total annual medical costs attributable to obesity [11,12].

Over the past few years, researchers, popular press and the television news media have paid considerable attention to the effect that farm subsidies have on dietary habits and obesity. A search of major US newspapers reveals that in the past two years there have been over 20 articles published on U.S. farm policy and how it encourages the production of commodities that have been linked to obesity.

Prominent researchers in the field have concluded that US farm subsidies have had a negligible impact on obe- 
sity [14]. This conclusion is not disputed. However, even small increases in obesity rates are associated with higher health care expenditures. The primary intent of this study is to break down the linkages from farm subsidy to health expenditure and shed light on the unintended implications of the farm subsidy program.

\section{Background}

During the early 1900s, the relocation of individuals from rural areas to the cities and the increasing world demand for food resulted in an increase in income for US farmers [15]. The end of World War One brought an increase in European food production and a decline in the international demand for food. Understandably, the price of food and the income of US farmers decreased. Although pressure mounted for the government to intervene and secure the financial viability of domestic farms, it wasn't until the Great Depression and Franklin Roosevelt's New Deal that a combination of price supports, income supports and supply management were introduced.

With price supports, farmers are guaranteed a minimum price for their crops; the price is usually set higher than the free market price, and the government maintains the high price by purchasing the surplus. Under ideal circumstances, when the market price does increase the government sells its stock. The drawback of this policy is that the government pays significant storage costs while waiting for the market price to increase.

Demand for US crops improved in the early 1970s when President Nixon arranged to sell 20 million tons of grain to the Soviet Union at subsidized prices. The Soviet Union endured a poor harvest season and looked to the world wheat market to thwart the looming food crisis. As a result of the agreement with the Soviet Union, the Department of Agriculture paid \$140 million in subsidies to US traders. Shortly thereafter, there was a shortage in the grain market which resulted in an increase in grain prices [16].

In order to increase farm production, while at the same time decrease its role as a buyer of farm products, the government began subsidy program in 1985. This program began with cotton and rice; soybeans, wheat and feed grains were added in later years. Under this policy, farmers can sell their crops on the open market at a price that is below the price support price and the government reimburses the farmer for the difference. Theoretically, under these circumstances, the farmer has an incentive to increase production thereby increasing income. Further, if the price reduction is passed on to the consumer, there is potential that the consumer may consume more than they otherwise would consume had the government not intervened.

Empirical results suggest that the effect of US farm subsidies on commodity prices is "mixed and modest", with the magnitude and direction dependent on the specific commodity [17]. Notwithstanding the magnitude of the price effects, farm subsidies in combination with the restriction of sugar imports are responsible for the growth of high fructose corn syrup (HFCS) as a caloric sweetener and the accelerated growth of an industry of highly processed inexpensive foods $[18,19]$.

HFCS is a unique product that costs less than sugar and can be used with a variety of foods. It is processed from hydrolyzed corn starch, contains a high level of fructose (about 50\%) and a simple sugar carbohydrate. In an attempt to save money, food manufacturers incorporate HFCS into a variety of food production. In fact, between 1970 and 1990, the consumption of HFCS in the United States increased 1000\% [20].

In an effort to substantially alter the farm subsidy program, the 1996 farm bill directed the government to offer payments to farmers based on past production rather than current production. The purpose of the change in policy was to encourage the diversification of agricultural production that would allow for improved global food market competition. Unfortunately, declining commodity prices and farm income prompted legislation that fostered additional government's subsidization of the farm Industry. From 1998 to 2007, farmers received an annual average of $\$ 16.4$ billion in government payments [21]. The most recent Farm Bill attempts to decrease the role that the US government plays in domestic farming by decreasing commodity subsidies by about $\$ 5$ billion per year [22].

\section{METHODOLOGY}

The link from the farm subsidy to health care expenditures begins with the farmer. When a farmer receives a production subsidy from the federal government, the cost of farming decreases and the farmer has an incentive to plant more of the subsidized crops; more production means higher income. Once the crops are harvested, they are sold by the farmers to food producers.

The over planting of crops linked to subsidized farming can lead to a decrease in the price that food producers must pay to purchase these particular commodities. Empirical results linking subsidies to commodity prices yield mixed results; research suggests that agricultural subsidies lead to a 6 to 10 percent decrease in commodity prices [23-26]. This range is reflective of the array of commodities that are associated connected to farm subsidies.

The food producer then takes all the inputs necessary, of which farm commodities are included, to make food that is available for the consumer to purchase. The price paid by the consumer for the final food product is influenced by many factors, one of which is commodity 
prices. Empirical analysis, which considers a whole host of factors that influence consumer prices, suggests that for every 1 percent decline in commodity prices, food prices decrease by 0.27 percent [27]. This measure of commodity price-food price responsiveness suggests that agricultural subsidies result in 1.6 to 2.7 percent lower food prices for consumers $[17,27]$. Step by Step calculations are presented in Table 1.

For most goods, when the price of food decreases, consumers generally increase the quantity purchased (think Big Gulp). Of course other factors play into whether consumers increase food consumption (i.e., taste, food additions). That said, unless there is an increase in the calories burned, the increased consumption of food products leads to weight gain and the possibly of obesity. Recent research suggests that a 1 percent decrease in the price of food consumed at home corresponds to a 0.039 percent increase in body mass index (BMI) [27-30]. This measure of food price-BMI responsiveness suggests that agricultural subsidies result in a 0.062 to 0.105 percent increase in BMI. This translates to a BMI increase of between 0.018 and 0.029 for a person with an average BMI of 28.

The final link in this chain is the connection of BMI to health care expenditures. Several studies have estimated the relationship between BMI and health care expenditures. Pronk et al. estimated that a one unit increase in BMI results in a $1.9 \%$ increase in median billed charges [31]. The Pronk study, however, used the full-range of
BMI and thus assumed that the cost response of a 1 unit increase in BMI is constant across all BMI levels. In a 2006 study, Wang et al., estimated the increase in health care costs per unit increase in BMI for individuals with BMI between 25 and 45 [32]. In their study, Wang et al. used data from approximately 36,000 individuals who selected an indemnity or PPO medical insurance plan. Individual medical and pharmaceutical claims information from January 2001 to December 2002 was collected. They found that medical costs and pharmaceutical costs increased $4 \%$ and $7 \%$, respectively, per unit increase in BMI.

The implications of all these links are not trivial. There is evidence to suggest that agriculture subsidies decrease commodity prices; lower commodity prices can in turn lead to a reduction in retail food prices; and a decrease in retail food prices can lead to increases in BMI. Further, increases in BMI can result in higher health care costs. In other words, by looking all these links as part of a larger set of relationships, we find that agricultural subsidies have the potential to influence health care expenditures.

\section{RESULTS}

Using our elasticity chain, we find there is potential for medical expenditures to be 0.072 to 0.116 percent higher and pharmaceutical expenditures are 0.126 to 0.203 percent higher than they would otherwise be without US farm subsidies. In terms that may be easier to comprehend, at the upper bound, medical expenditures, in the

Table 1. The effects farm subsidies have on health spending.

\begin{tabular}{|c|c|c|c|c|}
\hline Step & Action & Evidence & Effect & Calculation \\
\hline 1 & $\begin{array}{l}\text { Subsidies result in a } \\
\text { decrease in commodity } \\
\text { prices. }\end{array}$ & $\begin{array}{l}\text { Agricultural Subsidies lead to a } 6 \% \\
\text { to } 10 \% \text { decrease in commodity prices } \\
\text { (Babcock, 2004; Gardner, 2002; } \\
\text { Westcott and Price, 2001; Goodwin } \\
\text { and Mishra, 2005) }\end{array}$ & $\begin{array}{l}6 \% \text { to } 10 \% \text { decrease in commodity } \\
\text { prices }\end{array}$ & \\
\hline 2 & $\begin{array}{l}\text { A decrease in commodity } \\
\text { prices leads to a decrease } \\
\text { in retail food prices for } \\
\text { consumers. }\end{array}$ & $\begin{array}{l}\text { A } 1 \% \text { decrease in commodity prices } \\
\text { leads to } 0.27 \% \text { decrease in food } \\
\text { prices (Paul and McDonald, 2003) }\end{array}$ & $\begin{array}{l}\text { A } 6 \% \text { to } 10 \% \text { decrease in commodity } \\
\text { prices leads to a } 1.62 \% \text { to } 2.7 \% \\
\text { decrease in food prices }\end{array}$ & $\begin{array}{l}6 \% \times 0.27 \%=1.62 \% \\
10 \% \times 0.27=2.7 \%\end{array}$ \\
\hline \multirow[t]{2}{*}{3} & $\begin{array}{l}\text { A decrease in retail food } \\
\text { prices results in increased } \\
\text { food consumption and } \\
\text { increases in BMI. }\end{array}$ & $\begin{array}{l}\text { A } 1 \% \text { decrease in retail food prices } \\
\text { leads to a } 0.039 \% \text { increase in BMI } \\
\text { (Chow et al., 2004; Cawley, 1999; } \\
\text { Lakdawala and Philipson, 2002; } \\
\text { Chou et al., 2004) }\end{array}$ & $\begin{array}{l}\text { A } 1.62 \% \text { to } 2.7 \% \text { decrease in food } \\
\text { prices leads to a } 0.063 \% \text { to } 0.105 \% \\
\text { increase in BMI }\end{array}$ & $\begin{array}{l}1.62 \% \times 0.039 \%=0.063 \% \\
2.7 \% \times 0.039 \%=0.105 \%\end{array}$ \\
\hline & & & $\begin{array}{l}\text { For an individual with a } \mathrm{BMI}=28 \text {, a } \\
0.063 \% \text { to } 0.105 \% \text { increase results in } \\
\text { a BMI increase of } 0.018 \text { to } 0.029\end{array}$ & $\begin{array}{l}28 \% \times 0.063 \%=0.018 \\
28 \% \times 0.105 \%=0.029\end{array}$ \\
\hline 4 & $\begin{array}{l}\text { Increases in BMI lead to } \\
\text { increases in medical and } \\
\text { pharmaceutical expenses. }\end{array}$ & $\begin{array}{l}\text { For every } 1 \text { unit increase in BMI, } \\
\text { medical expenses increases } 4 \% \text { and } \\
\text { pharmaceutical expenses increases } \\
7 \% \text { (Wang et al., 2006). }\end{array}$ & $\begin{array}{l}\text { Medical expenditures are } 0.072 \% \text { to } \\
0.116 \% \text { higher, and Rx expenditures } \\
\text { are } 0.126 \% \text { to } 0.203 \% \text { higher than } \\
\text { they would otherwise be without } \\
\text { subsidies. }\end{array}$ & $\begin{array}{l}\text { Medical } \\
0.018 \% \times 4 \%=0.072 \% \\
0.029 \% \times 4 \%=0.116 \% \\
\text { Pharmaceutical } \\
0.018 \% \times 7 \%=0.126 \% \\
0.029 \% \times 7 \%=0.203 \%\end{array}$ \\
\hline
\end{tabular}


presence of farm subsidies, may be $\$ 1.16$ higher for every $\$ 1000$; and in the presence of farm subsidies, pharmaceutical expenditures may be $\$ 2.03$ higher for every $\$ 1000$.

Again, realizing that these are potential effects, not actual effects, for every $\$ 1$ billion in medical expenditures, farm subsidies may increase expenditures by approximately $\$ 1.16$ million. Although to some, the increases in health expenditures may appear quite modest, the impact at a national level cannot be minimized; the Medicare and Medicaid programs finance 19 percent and 15 percent, respectively, of the nearly $\$ 2.6$ trillion in national health expenditures [33].

\section{DISCUSSION}

In this paper, we use a series of measures (elasticities) to connect farm subsidies to health care expenditures. The intention is not to imply there is a direct causal link between farm subsidies and medical expenditures. We are simply creating a forum to discuss the possibility that farm subsidies are connected to medical expenditures.

Notwithstanding the policy implications derived from this work, limitations to this study must be acknowledged. One shortcoming is that the measure of the responsiveness of food prices to changes in commodity prices is not specific to foods and commodities linked to obesity. Likewise, the measure of the responsiveness of BMI to changes in food prices is not specific to obesity related foods. It is reasonable to assume that if more specific measures were available, the impact of agricultural subsidies on health expenditures may be higher or lower.

Finally, we do recognize that farm subsidies can also affect contamination of ground water, diesel exhaust, vegetable dust exposures, etc., which can also influence medical care expenditures. Furthermore, better methods of transportation, storage, freezing and preparation of precooked packages also contributes to the increased availability of farm related products and lower food prices. Even in the presence of these considerations, the conceptual link between farm subsidies and health expenditures cannot be overlooked.

\section{CONCLUSION}

The data used in this study are from the United States, but subsidizing farming is not unique to the United States. For example, agricultural subsidies are used in the European Union, Japan, and some African nations (i.e. Malawi) [34]. In many of these same nations, obesity rates are rising as are the strains on global health care budgets. As nations experience the health care consequences of rising obesity rates, such as higher rates of diabetes and coronary heart disease, they may in fact need to look to their agriculture policies as a potential source of the problem.
As Michael Pollan, author of the Omnivore's Dilemma, so succinctly states, "The nation's agricultural policies operate at cross-purposes with its public health objecttives" [35]. The US farm policy program encourages the production of commodities that have been linked to obesity. At the same time, the government, at the federal and state level, is engaged in and funding many programs that are designed to reduce the prevalence of obesity and health care costs in our country. For example, the majority of the $\$ 1$ billion appropriated by Congress for disease prevention as part of the economic stimulus package supports the CDC's initiative to curb rates of obesity, heart disease and other chronic conditions [36]. This nonalignment of agriculture and public priorities needs to be addressed; and there is a compelling case for subsidizing the production of commodities that contributes to the public's health rather than detracts from it.

\section{REFERENCES}

[1] World Health Organization Fact Sheet (2010) Overweight and obese.

http://www.who.int/mediacentre/factsheets/fs311/en/inde x.html

[2] Centers for Disease Control and Prevention (2004) Prevalence of overweight and obesity among adults: United States, 2003-2004.

http://www.cdc.gov/nchs/products/pubs/pubd/hestats/obe se03_04/overwght_adult_03.htm

[3] Bray, G.A., Nielsen, S.J. and Popkin, B.M. (2004) Consumption of high-fructose corn syrup in beverages may play a role in the epidemic of obesity. American Journal of Clinical Nutrition, 79, 537-543.

[4] Pi-Sunyer, F. (2002) Medical complications of obesity in adults. In: Fairburn, C.G. and Brownell, K.D., Eds., Eating Disorders and Obesity: A Comprehensive Handbook. 2nd Edition, Guilford Press, New York.

[5] Quesenberry, P., Caan, B. and Jacobson, A. (1998) Obesity, health services use, and health care costs among members of a health maintenance organization. Archives of Internal Medicine, 158, 466-472. doi:10.1001/archinte.158.5.466

[6] Raebel, M.A., Malone, D.C., Conner, D.A., Xu, S., Porter, J.A. and Lanty, F.A. (2004) Health services use and health care costs of obese and nonobese individuals. Archives of Internal Medicine, 164, 2135-2140. doi:10.1001/archinte.164.19.2135

[7] Organization for Economic Co-operation and Development (OECD) Health Data (2006) How does the United States compare.

http://docs.google.com/gview?a=v\&q=cache:Gly4VVgc4 pYJ:www.oecd.org/dataoecd/29/52/36960035.pdf+health + spending + oecd $+2006 \&$ hl=en\&gl=us\&sig=AFQjCNGO NhHiBbeh_kDRb5-A14JYaSTASg.

[8] Thorpe, K.E., Florence, C.S., Howard, D.H. and Joski, P. (2004) The impact of obesity on rising medical spending. Health Affairs, 23, W4-480. 
[9] Wolf, A. and Colditz, G. (2007) The cost of obesity: The US perspective. Pharmacoeconomic, 5, 35-37.

[10] Wolf, A. and Colditz, G. (1998) Current estimates of the economic cost of obesity in the United States. Obesity Research, 6, 97-106. doi:10.1002/j.1550-8528.1998.tb00322.x

[11] Finkelstein, E.A., Fiebelkorn, I.C. and Wang, G. (2003) National medical spending attributable to overweight and obesity: How much and who's paying? Health Affairs, 22. doi:10.1377/hlthaff.w3.219

[12] Finkelstein, E.A., Fiebelkorn, I.C. and Wang, G.J. (2004) State-level estimates of annual medical expenditures attributable to obesity. Obesity Research, 12, 18-24. doi:10.1038/oby.2004.4

[13] Thompson, D. and Wolf, A. (2001) The medical-care cost burden of obesity. Obesity Review, 2, 189-197. doi:10.1046/j.1467-789x.2001.00037.x

[14] Alston, A., Rickard, B. and Okrent, M. (2010) Farm policy and obesity in the United States. Choices, 25.

[15] Effland, A.U.S. (2000) Farm policy: The first 200 Years. Agricultural Outlook, 21-24.

[16] Bundy, W. (1998) Tangled web: The making of foreign policy in the Nixon presidency. Hill and Wang, New York.

[17] Alston, J.M., Sumner, D.A. and Vosti, S.A. (2008) Farm subsidies and obesity in the United States: National evidence and international comparisons. Food Policy, 33, 470-479. doi:10.1016/j.foodpol.2008.05.008

[18] Park, Y.K. and Yetley, E. (1993) Intakes and food sources of fructose in the United States. American Journal of Clinical Nutrition, 58, 73S-47S.

[19] Smith, S.M. (1998) High fructose corn syrup replaces sugar in processed food, Environmental Nutrition, 11, 7-8.

[20] Bray, G., Bouchard, C. and James, W., Eds. (1998) Handbook of obesity. Marcel Dekker, New York.

[21] Engemann, K. (2008) US farm subsidies Liber8. Economic information newsletter. Federal Reserve Bank of St. Louis.

[22] United States Department of Agriculture (2008) 2008 farm bill. http://www.usda.gov/wps/portal/usda/farmbill2008?navid =FARMBILL2008.

[23] Gardner, B. (2002) US agricultural policies since 1995, with a focus on market effects in grains and oilseeds. Working Paper 02-17, Department of Agricultural Economics, University of Maryland.

[24] Westcott, P. and Price, J. (2001) Analysis of the US commodity loan program with marketing loan provisions. Agricultural Economic Report 801, United States Department of Agriculture.

[25] Goodwin, G. and Mishra, A. (2005) Are decoupled farm payments really decoupled? An empirical evaluation. American Journal of Agricultural Economics, 88, 73-79. doi:10.1111/j.1467-8276.2006.00839.x

[26] Morrison, P. and MacDonald, J. (2003) Tracing the effects of agricultural commodity prices and food costs. American Journal of Agricultural Economics, 85, 633646. doi:10.1111/1467-8276.00461

[27] Cawley, J. and Kirwan, B. (2005) Pour some sugar on me: The contribution of US agricultural policy to obesity. Unpublished manuscript.

[28] Chou, S., Grossman, M. and Saffer, H. (2004) An economic analysis of adult obesity: Results from the behavioral risk factor surveillance system. Journal of Health Economics, 23, 565-587. doi:10.1016/j.jhealeco.2003.10.003

[29] Cawley, J. (1999) Rational addiction, the consumption of calories and body weight. Dissertation, University of Chicago, Chicago.

[30] Lakdawalla, D. and Philipson, T. (2002) The growth of obesity and technological change: A theoretical and empirical investigation. Research working paper 8965, National Bureau of Economic.

[31] Pronk, N.P., Goodman, M.J., O’Connor, P.J. and Martinson, B.C. (1999) Relationship between modifiable health risks and short-term health care charges. JAMA, 282, 22352239. doi:10.1001/jama.282.23.2235

[32] Wang, F.F., McDonald, T., Bender, J., Reffitt, B., Miller, A. and Edington, D.W. (2006) Association of healthcare costs with per unit body mass index increase. Journal of Occupational and Environmental Medicine, 48, 668-674. doi:10.1097/01.jom.0000225045.77734.f4

[33] Centers for Medicare and Medicaid Services (2009) Fact sheet, national health expenditures. http://www.cms.hhs.gov/NationalHealthExpendData/25 NHE Fact Sheet.asp\#TopOfPage

[34] European Commission (2009) Financial programming and budget. http://ec.europa.eu/budget/index_en.htm

[35] Pollan, M. (2007)You are what you grow. New York Times. http://www.nytimes.com/2007/04/22/magazine/22wwlnle de.t.html.

[36] Fox, M. (2009) US states to get significant obesity money. Reuters. 